\title{
Bare Singular Reference to Kinds
}

\author{
Edit Doron \\ The Hebrew University of Jerusalem
}

\section{Introduction}

This paper is an attempt to apply Chierchia's 1998 Neo-Carlsonian approach to languages such as Hebrew and Brazilian Portuguese, which allow bare singular reference to kinds. This is a problem, since Chierchia's nominalization type-shift from properties to kinds is inapplicable to singular properties.

Bare singular reference to kinds is allowed in Hebrew, (1a), in contrast to English, which does not allow singular indefinites to denote kinds, (1b). At the level of ordinary objects, as in (1c), bare singulars in Hebrew seem to parallel indefinite singulars in English:

a. namer hu min be sakanat hakxada tiger he kind in danger (of) extinction

'The tiger is a kind in danger of being extinct.'

b. * A tiger is a kind in danger of being extinct.

c. ra'iti namer / namer ša'ag I-saw tiger / tiger roared 'I saw a tiger.'/ 'A tiger roared.'

The bareness of tiger in the Hebrew (1a) is necessary to allow it to function as a name of the kind tiger, unlike the English a tiger. It is reasonable to think, moreover, that bare nouns should be able to name kinds in any language that allows bare nouns in the first place. This is the position of Gerstner and Krifka 1993 and Krifka 1995. But this position cannot be maintained. There are languages where bare nouns are allowed, either in the singular or in the plural, or in both, but nevertheless these bare nouns do not denote kinds (rather, they require definite articles for kind denotation). Such languages are for example Italian, Hungarian, Standard Arabic (and Arabic dialects), as shown in (2), (3) and (4):

- $\underline{\text { Italian }}$

a. Elefanti di colore bianco hanno creato in passato grande curiosità 'White-colored elephants raised a lot of curiosity in the past.' (Longobardi 2001 (6a))

b. * Elefanti di colore bianco sono estinti 'White-colored elephants have become extinct.' (L (13a)) 
- Hungarian

a. Péter verset/ verseket olvas

Peter poem-Acc/poems-Acc read

'Peter is reading a poem/poems.' (Farkas \& Swart 2003 (21))

b. * Medve/Medvék elterjedtek

bear/bears widespread-Pl. (F\&S (126))

c. * Medve okos /* Medvék okosak bear intelligent / bears intelligent-Pl. (F\&S (123))

- Standard Arabic

namir-un aşfar-un tațawwara min an-namir-i al-ahmar tiger-NOM yellow-NOM developed from the-tiger-GEN the-red 'A yellow tiger developed from the red tiger.' $\sqrt{\text { ordinary obj. } / * \text { kind }}$ i.e. not: 'The yellow tiger developed from the red tiger.'

(Shireen Siam p.c.)

The bareness of indefinites is therefore not a sufficient condition for kind reference. We are thus faced with the additional question of why bare singulars can denote kinds in Hebrew but not in Hungarian or Arabic, though all three allow bare singular nouns.

Before moving on, I provide a few attested examples in (5), since the use of bare singular count nouns to refer to kinds has not been noted in Hebrew before:

a. eyze xaya mešamešet ke semel ha-refu'a?

which animal serves as symbol (of) the-medicine

'Which animal serves as the symbol of medicine?'

naxaš

snake 'The snake.' (from children's trivia game)

b. bi ršima zo nixlalim lutra, namer, xatul xolot in list this are-included otter, tiger, cat (of) sands

ve kama miney leta'ot.

and several species (of) lizards

'This list includes the otter, the tiger, the sand cat and several species of lizards.' (Haaretz 6.3.2003, b6)

c. be yamim ele menase cevet mada'anim sqoti le-šabet in days these tries team (of) scientists Scottish to-clone namer tasmani, še ,nikxad raq b a-me'a ha-20 
tiger Tasmanian, that became-extinct only in the-century the-20

'A Scottish team of scientists is trying these days to clone

the Tasmanian tiger, which only became extinct in the $20^{\text {th }}$ century.'

(Haaretz 22.4.03, a14)

d. calfonit xuma nefoca mi kav ha-roxav

Proxylocopa brown common from line (of) the-latitude

šel yam ha-melax darom-a

of sea (of) the-salt south-ALL

'The brown bee is common from the Dead Sea southward.'

The examples in (6) show kind-referring bare nouns in various grammatical positions: subject in (6a), part of a conjoined NP in (6b), object of a preposition in (6c), object of a verb in (6d). All the examples in (6) can be reproduced with bare plurals as well, and with definite singular or plural nouns. I will turn to these variants later.

a. namer hit'ara kan, aval arye lo tiger struck-roots here, but lion not

'The tiger became indigenous here, but not the lion.'

b. namer ve arye hem minim qrovim tiger and lion they species related 'The tiger and the lion are related species.'

c. namer hitpate'ax mi xatul tiger developed from cat 'The tiger evolved from the cat.'

d. mi bxina evolucyonit, xatul maqdim namer from perspective evolutionary, cat precedes tiger 'From an evolutionalry perspective, the cat precedes the tiger.'

Hebrew is not the only language where singular nouns can refer to kinds without an article, but not all of these languages are problematic for Chierchia's theory. Chinese for example is not a problem for his account. A bare noun like panda in (7a) refers to a kind, but this is so since presumably there is no morphological singular/ plural distinction to begin with, as shown in (7b), and consequently the noun panda is actually number neutral rather than singular:

- Mandarin Chinese (Cheng \&Sybesma 1999)
a. xíongmao kuai júe zhǒng le panda soon extinct ASP 'The panda will soon be extinct.'
b. wǒ kànjiàn xíongmao le 
I see panda ASP 'I saw some panda/pandas.'

There are also languages such as Hindi and Russian, where there is number inflection, yet bare singulars nevertheless refer to kinds, as in (8a). This is related to the fact that there is no definite article in these languages, and consequently a bare noun can be interpreted as definite, as in (8b):

- Hindi (Dayal 1992, 1999)

a. kutta aam jaanvar hai dog common animal be-PRES

'The dog is a common animal.'

b. kutte bhaunk rahe haiN dogs bark-PROG-PRES

'The/some dogs are barking.'

The attempt I make here is to maintain Chierchia's theory in the face of languages which have number and definiteness marking in noun phrases, but nevertheless allow bare singulars to refer to kinds. This is the case of Hebrew, and, as far as I have been able to establish, also of Brazilian Portuguese (in accordance with the description of Schmitt and Munn 1999, 2000, but contra Müller 2001). In (9a), a bare singular noun is used for kind reference, and in (9b) for an existential assertion. In (9c) we see that Brazilian Portuguese marks both number and definiteness, and, unlike Hebrew, it even has an indefinite article. Also unlike Hebrew (cf. (1c)), the bare noun $d o g$ in a simple episodic sentence like $(9 \mathrm{~b})$ is number neutral:

- Brazilian Portuguese

a. Onça é uma especie em perigo de extinçaõ tiger is a species in danger of extinction

'The tiger is a species in danger of extinction.'

b. Eu ouvi cachorro

I heard dog

'I heard a dog/ dogs.'

c. Eu ouvi um cachorro/ cachorros/ o cachorro/ os cachorros

I heard a dog/ dogs / the dog / the dogs

'I heard a dog/ dogs/ the dog/the dogs.' (Keren Segre p.c.)

\section{Chierchia's Approach}

\subsection{Plural Reference to Kinds}

Carlson 1977 interprets English bare plurals as kinds. In Chierchia's version, English bare plurals basically denote plural properties, but when they are used as 
arguments, as in (10), they are shifted by a covert "cap" nominalization operator, shown in (11), which derives kinds. For each property $\mathrm{P},{ }^{\wedge} \mathrm{P}$ is defined in each world as that member of the extension of $\mathrm{P}$ which includes all the others as parts, if there is a unique one, and undefined otherwise. The part relation is encoded in (11) as an order relation. If $P$ is plural, its extension includes sets of objects, and the derived kind is defined in each world as the maximal such set.

$$
\begin{aligned}
& \text { Dogs are common. } \\
& { }_{\mathrm{P}}=\max _{\leq} \mathrm{x} P(\mathrm{x})
\end{aligned}
$$

When bare plurals appear as arguments of episodic predicates which apply to ordinary objects, rather than kinds, an additional type-shift is postulated, the Derived Kind Predication defined in (12a), which existentially quantifies over the property of being an instance, or part, of the kind. This property is numberneutral, it applies both to individuals and to sets of individuals. (12b) is an example where the DKP applies, since barking is a property of ordinary objects, not kinds:

a. Derived Kind Predication (DKP): (Chierchia 1998)

If $P$ applies to objects and $k$ denotes a kind, then

$\mathrm{P}(\mathrm{k})=\exists \mathrm{x} \quad[\mathrm{x} \leq \mathrm{k} \wedge \mathrm{P}(\mathrm{x})]$

b. Dogs are barking.

barking $(\cap$ dogs $) \Leftrightarrow$ (via DKP) $\exists \mathrm{x}\left[\mathrm{x} \leq{ }^{\cap}\right.$ dogs $\wedge$ barking (x) ]

The DKP type-shift makes sure that bare plurals have narrow scope, for example with respect to negation, as in (13a). I will not go into the details here, but the only reading that the DKP assigns to (13a) is (13b), where the existential quantifier has narrow scope:
a. Dogs are not barking.
b. $\neg \exists \mathrm{x}\left[\mathrm{x} \leq{ }^{\cap} \operatorname{dogs} \wedge\right.$ barking $(\mathrm{x})$ ]

This is different from the existential quantification associated with the article $a$, an operator which can be scoped in various ways, yielding the two different readings in (14):
a. A dog is not barking.
b. $\neg \exists \mathrm{x}[\operatorname{dog}(\mathrm{x}) \wedge$ barking $(\mathrm{x})]$
c. $\exists \mathrm{x}[\operatorname{dog}(\mathrm{x}) \wedge \neg$ barking $(\mathrm{x})]$

If the sentence is habitual, such as (15a), the habitual aspect of the sentence is interpreted as the modal operator $G n$ together with the accomodation of a contextual variable $\mathrm{C}$, in (15b). Here again the property quantified on is the property of being an instance of the kind, which, as stated above, is numberneutral: 
(15)
a. Dogs bark.
bark ( $($ dogs)
b. $\operatorname{Gnx}, \mathrm{s}\left[\mathrm{x} \leq \cap^{\cap} \operatorname{dogs} \wedge \mathrm{C}(\mathrm{x}, \mathrm{s})\right][\operatorname{bark}(\mathrm{x}, \mathrm{s})]$

\subsection{Definite Reference to Kinds}

In the case of singular nouns, nominalization does not derive a kind from the property. If $\mathrm{P}$ in (11) above is singular, then, since there is no order relation assumed between objects, $\max$ will be uniquely defined only if the extension of $\mathrm{P}$ is a singleton. But it is inappropriate to define a kind which has a single instantiation in each world. Therefore the property denotation of a singular noun cannot be shifted to kind-reference, which is why we do not get bare singulars in English:

* Dog is common

But English has singular reference to kinds, and Chierchia considers that it is definiteness which is the key ingredient in deriving the kind reading of singular noun phrases:

The dog is common.

According to his analysis, the definite generic article shifts the singular property $d o g$ to the atomic object g( $\mathrm{l}$ MASS dog), the group which is the mereological sum of all the dogs (as in Link's 1983 treatment of plurals), rather than a kind, which is a set.

The main motivation for the distinction between kinds and groups is that the DKP does not apply to the latter. Since a group is an ordinary object, not a set, there is no type mismatch to be adjusted in sentences containing predicates of ordinary objects. This accounts for the lack of an indefinite existential reading for the definite noun phrase in (18b), which is found for the bare plural in (18a):

(18) a. Tigers are roaring in the zoo.

b. The tiger is roaring in the zoo.

\section{Covert Definite Reference to Kinds}

\subsection{Hindi}

Dayal 1992, 1999 discusses Hindi, a language where bare singular nouns are grammatical. Dayal proposes that bare nouns do not have both definite and indefinite readings, rather they are always definite. Properties of objects always come with an ingrained maximality operator which yields the maximal collection 
in the context, either singular or plural. At the level of kinds, singular nouns name groups, whereas plural nouns name kinds. Since Chierchia's DKP is the only source of existential quantification in bare nouns, and since the DKP is available only for kinds but not for groups, Dayal's system allows an indefinite interpretation for bare plural nouns only, not for singulars. And this, she claims, is indeed the fact in Hindi, only plural but not singular nouns can be interpreted existentially. Indeed, in sentences with kind predicates, the bare singular noun is definite:

$$
\begin{aligned}
& \text { kutta aam jaanvar hai } \\
& \text { dog common animal be-PRES } \\
& \text { 'The dog is a common animal.' }
\end{aligned}
$$

In generic sentences, the bare singular noun has either group reference or object reference, and both are definite:

kutta bhauNktaa hai

dog bark-PRES

'The dog barks.' (group or individual)

In episodic sentences too a singular noun is definite:

$$
\begin{aligned}
& \text { kutta bhaunk rahaa hai } \\
& \text { dog bark-PROG-PRES }
\end{aligned}
$$

'The dog/*a dog is barking.'

In the plural, on the other hand, bare nouns in episodic sentences can be interpreted as indefinite:

$$
\text { kutte bhaunk rahe haiN }
$$

dogs bark-PROG-PRES

'The dogs/Some dogs are barking.'

A problem with this approach is reported by Dayal. There are examples of singular nouns which can be interpreted as indefinite, in object position:

$$
\begin{aligned}
& \text { anu kitaab paRh rahii hai } \\
& \text { Anu book read-PROG-PRES } \\
& \text { 'Anu is reading the book/a book.' }
\end{aligned}
$$

Dayal suggests that (23) is an example of noun incorporation. Accordingly, her system includes both a DKP rule and an incorporation rule, both accounting for the indefinite interpretations of bare nouns. On the basis of data from Hebrew and Brazilian Portuguese, the present study will conclude that incorporation indeed plays a role in the interpretation of bare nouns. But once incorporation is part of the interpretive system, the DKP becomes obsolete. 


\subsection{Russian}

Chierchia's account of bare singular arguments in Russian depends on the lack of both definite and indefinite articles in this language, which allows covert application of the l-operator and existential closure. As for kind reference, in Russian too, a singular noun cannot be shifted via the nominalization type-shift in (11) to refer to a kind, for the same reason as in English: there are no kinds which have a single instance in each world. But since in Russian there also is no definite generic article to block the free type-shift from properties to groups, a property such as $d o g$ can freely type-shift to the group g(l MASS dog) for which English needs the generic definite article:

a. U sobaki i volka obšie predki to dog-SG-GEN and wolf-SG-GEN common ancestors 'The dog and the wolf have common ancestors.'

b. Sobaki obyazany svoimi kačestvami volku dogs owe their qualities wolf-SG-DAT 'Dogs owe their qualities to the wolf.'

c. Golanskaya ovčarka proizošla ot belgiyskoy ovčarki dutch sheep-dog descends from belgian sheep-dog 'The Dutch Shepherd descends from the Belgian shepherd.' (attested examples, Olga Kagan p.c.)

\section{Brazilian Portuguese and Hebrew}

Analyses like Chierchia and Dayal which are based on the lack of a definite determiner in Slavic and Hindi cannot be extended to Brazilian Portuguese and Hebrew, since these languages do explicitly mark definiteness. According to both Chierchia and Dayal, singular nouns canot refer to kinds without being definite. But in fact this is not so in these languages. Schmitt and Munn 1999 conclude that this refutes Chierchia's typology, and they propose a syntactic approach.

I will nevertheless attempt to solve the problem within a semantic typology. The problem is that singular properties cannot be shifted to kinds by the nominalization operator. But this is actually a welcome property of Chierchia's system. Upon inspecting the distribution of kind-referring bare singulars in Brazilian Portuguese and Hebrew, it turns out that they have a narrower distribution than kind-referring plurals and mass nouns. It would therefore be wrong to propose a single operator for the kind interpretation of singular and plural properties in argument position.

There are at least two additional independently motivated operations by which languages interpret a property in argument position. One is incorporation, 
as in van Geenhoven's 1998 approach, which derives an existential interpretation for properties:

$$
\mathrm{P}(\mathrm{Q})=\exists \mathrm{x}[\mathrm{Q}(\mathrm{x}) \wedge \mathrm{P}(\mathrm{x})]
$$

The other is the specific interpretation of the subject of a categorical judgment (in the sense of Kuroda 1973). According to Ladusaw 1994, the subject of a (nonquantificational) categorical judgment is an individual, rather than a property which may fall under the scope of existential closure. I assume that in languages which grammatically mark the subject of a categorical judgment (like wa marking in Japanese), a property in categorical subject position is shifted to the corresponding kind independently of the definite determiner. This is the case of Hebrew and Brazilian Portuguese. In other languages, such as Italian, Hungarian and Arabic, marking a noun phrase as a categorical subject includes marking it as definite.

In Hebrew, categorical subjects are marked by positioning them in a left peripheral position, or by means of contrastive focus intonation. A left peripheral position is often associated with a pronominal clitic (cf. Doron and Heycock 1999 and Heycock and Doron 2003). An example of such clitic is the pronominal clitic copula, which is typically optional in Hebrew, as shown in (26a), where reference to a kind is made by a definite noun-phrase. But since the interpretation of a bare singular as a kind depends on its being a categorical subject, the pronominal clitic marking this position is obligatory in (26b):

a. ha-namer (hu) nadir be arc-enu

the-tiger (he) rare in country-our

'The tiger is rare in our country.'

b. namer *(hu) nadir be arc-enu

tiger $*($ he) rare in country-our

'The tiger is rare in our country.'

\subsection{Episodic Sentences}

In Hebrew, bare singulars in episodic sentences denote singular individuals only, not pluralities:

ra'iti kelev. hu navax/ \# hem navxu

I-saw dog. he barked/ \# they barked

'I saw a dog. It barked/ \# They barked.'

Clearly this shows that there is no shift to kinds in (27), since the property quantified on is singular and not number neutral. Rather, this is a case of incorporation. There are also syntactic arguments for the incorporation analysis, in Danon 2002, such as the lack of Case marking in incorporated noun phrases. 
In Brazilian Portuguese, on the other hand, incorporation is interpreted as number neutral, as shown in (28). This is a well-known option for the interpretation of incorporated nouns, and it does not indicate that there is shift to kinds in these examples. It will become apparent below (in example (44)) that bare singular nouns in Brazilian Portuguese, as in Hebrew, are not interpreted by a shift to kinds in episodic sentences.

a. Ele comprou computador he bought computer 'He bought a computer/computers.' (S\&M 1999, (7d))

b. Tinha livro espalhado pelo chão had book spread over-the floor 'There were books all over the floor.' (S\&M 1999, (34))

c. Tem criança na sala e ela está/ elas estã ouvindo has child in-the room and she is/ they are listening 'There is a child/are children in the room and she/they are listening.' (S\&M 2000, (49))

For the case of bare plurals, we can assume in a parallel fashion that episodic sentences are interpretable by incorporation. We can therefore dispense with Chierchia's DKP, since existential quantification is accounted for directly by incorporation and does not depend on a type-shift to kinds:

a. noveax kelev

barks dog 'A dog is barking.'

barking (dog) $\Leftrightarrow$ (via incorporation) $\exists x[\operatorname{dog}(\mathrm{x}) \wedge$ barking $(\mathrm{x})]$

b. novxim klavim

bark dogs 'Dogs are barking.'

barking (dogs) $\Leftrightarrow$ (via incorporation) $\exists \mathrm{x}$ [ dogs (x) $\wedge$ barking (x) ]

Since incorporation applies at the level of the predicate rather than the sentence, both bare singulars and bare plurals only have narrow scope relative to negation, as in (30). (The same holds in Brazilian Portuguese.) This is different from English (cf. (13) and (14)), where singular indefinites, unlike bare plurals, can have wide scope relative to negation.
a. lo noveax kelev
not barks dog
'It is not the case that a dog is barking.'
$\Leftrightarrow$ (via incorporation) $\neg \exists x[\operatorname{dog}(x) \wedge$ barking $(x)]$
b. lo novxim klavim
not bark dogs 


\author{
'Dogs are not barking.' \\ $\Leftrightarrow$ (via incorporation) $\neg \exists \mathrm{x}[\operatorname{dogs}(\mathrm{x}) \wedge$ barking $(\mathrm{x})]$
}

\title{
4.2. Generic Sentences
}

Unlike the case of existential sentences, bare singulars in generic sentences denote both singular and plural instances of the kind, not only in Brazilian Portuguese, but also in Hebrew. This is indicative of kind denotation. It correlates with the fact that these bare singulars are categorical subjects, hence denote individuals. But since the present system does not include a DKP rule, there is no need to distinguish groups from kinds, and therefore a bare singular in categorical subject position can be interpreted as a kind, e.g. ${ }^{\circ}$ MASS (tiger) in the following examples. The habitual aspect of these sentences further introduces the $G n$ operator. Approaches such as Gerstner and Krifka 1993 which apply $G n$ directly to the property will derive only quantification over singular instances, contrary to these examples:

namer mitxaleq $b$ a-teref be ofen šivyoni tiger shares in the-prey in manner egalitarian 'The tiger shares the prey in an egalitarian manner.'

a. namer mit'asef leyad mekorot mayim b a-erev tiger gathers near sources (of) water in the-evening 'The tiger gathers near water sources in the evening.'

b. gathers near water sources ( $\cap$ MASS (tiger)) $\Leftrightarrow$

Gn $x, s[x \leq \cap$ MASS (tiger) $\wedge$ gather $(\mathrm{x}, \mathrm{s}) \wedge \mathrm{C}(\mathrm{x}, \mathrm{s})]$ [near-water-sources $(\mathrm{s})]$

In the logical form (33b), not only singular instances are included, but also plural ones. That there indeed is a shift from kinds to instances in these examples is demonstrated by the pronoun in (31), which refers to ordinary objects, and by the ambiguity in (34), depending on whether the pronoun is bound by the kind (in (34a)) or by its instances (in (34b)):

namer maziq le svivat-o tiger harms to environment-its 'The tiger is harmful to its environment.'

$\lambda \mathrm{x}$ [x harms $\mathrm{x}$ 's environment] ( $\cap$ MASS (tiger))

a. harms ( $\cap$ MASS (tiger), $\cap$ MASS (tiger)'s environment)

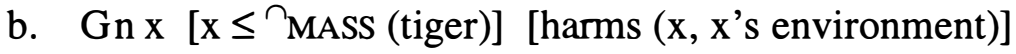


In Brazilian Portuguese, any type of collective predication is possible with bare singulars, as in (35): Criança briga uma com a outra child fights one with the other 'Children fight with each other.' (S\&M 1999 (35))

\subsection{Overt Definite Reference to Kinds}

Nouns in Hebrew are inflected for definiteness by the prefix $(h) a-$. Definite forms of all nouns, not just the singular ones as in English, can be used for kind (and generic) reference. This is shown for singular nouns in (36), plural nouns in (37), and mass nouns in (38):

(36) a. dinoza'ur/ha-dinoza'ur hu min še kvar nik'xad dinosaur / the-dinosaur he species that alreay extinct 'The dinosaur is a species which is already extinct.'

b. namer /ha-namer mit'asef leyad mekorot mayim b a-erev tiger / the-tiger gathers near sources water in the-evening 'The tiger gathers near water sources in the evening.'

(37) a. nemerim /ha- nemerim hem min mugan tigers / the-tigers they species protected 'Tigers are a protected species.'

b. dinoza'urim/ha-dinoza'urim hem min še kvar nik'xad dinosaurs / the-dinosaurs they species that alreay extinct 'Dinosaurs are a species which is already extinct.'

a. bronza / ha-bronza hi matexet raka bronze /the-bronze she metal soft 'Bronze is a soft metal.'

b. bronza / ha-bronza humce'a lifney pliz / ha-pliz bronze / the-bronze was-invented before brass/ the-brass 'Bronze was invented before brass.'

\subsection{Kind Interpretation of Categorical subjects}

We now note that while definite nouns can uniformly refer to kinds, this is not true of bare nouns. There are sentences where bare singular nouns cannot refer to kinds. These are sentences with predicates which can apply to ordinary objects, typically episodic sentences. In such sentences, the parallelism between definite and indefinite singulars breaks down. The definite noun still refers to the kind 
despite of episodicity or a possible reference to ordinary objects. The indefinite is only interpreted existentially. This is expected if bare singulars which are not categorical subjects are interpreted by incorporation:

a. ha-namer ne'elam me ezor-enu the-tiger disappeared from area-our 'The tiger disappeared from our area.' $\sqrt{ }$ obj./ $\sqrt{ }$ kind

b. namer ne'elam me ezor-enu tiger disappeared from area-our 'A tiger disappeared from our area.' $\sqrt{ }$ obj. $/ *$ kind

(40) a. ha-xulda higi'a le ostralya be 1770 the rat reached to Australia in 1770

'The rat reached Australia in 1770.' $\sqrt{ }$ obj./ $\sqrt{ }$ kind

b. xulda higi'a le ostralya be 1770

rat reached to Australia in 1770

'A rat reached Australia in 1770.' $\sqrt{ }$ obj. / * kind

a. elohimbara et ha-tanin b a-yom ha-xamiši god created ACC the-crocodile on the-day the-fifth 'God made/created the crocodile on the fifth day.' obj./kind

b. elohim bara tanin b a-yom ha-xamiši god created crocodile on the-day the-fifth 'God made a crocodile on the fifth day.' $\quad \sqrt{\text { obj. }} / *$ kind

a. profesor li xoker et ha-namer professor $\mathrm{Li}$ investigates $\mathrm{ACC}$ the-tiger 'Professor Li investigates the tiger.' $\sqrt{ }$ obj./ $\sqrt{ }$ kind

b. profesor li xoker namer professor $\mathrm{Li}$ investigates tiger 'Professor $\mathrm{Li}$ is investigating a tiger.' $\sqrt{ }$ obj. / * kind

a. babej himci et ha-maxšev

Babbage invented ACC the-computer

'Babbage invented the computer.' $\sqrt{ }$ kind

b. * babej himci maxšev

Babbage invented computer not 'Babbage invented the computer.' * kind

The same contrast is also found in Brazilian Portuguese: 
(44)

a. Ninguém sabe quem inventou a roda nobody know who invented the wheel

b. * Ninguém sabe quem inventou roda nobody know who invented wheel (S\&M 1999 (37))

This contrast follows if kind reference is possible for bare singulars only when they are marked as categorical subjects. Indeed when the bare singular in the above examples is syntactically fronted to a categorical subject position, it can refer to a kind:

a. maxšev babej himci

computer Babbage invented

'The computer Babbage invented.'

b. tanin elohim bara b a-yom ha-xamiši

crocodile god created on the-day the-fifth

'The crocodile God created on the fifth day.'

c. Roda ninguém sabe quem a-inventou

wheel nobody know who it-invented

'The wheel nobody knows who invented.' (Keren Segre p.c.)

Overt movement to a special syntactic position is one way to mark a categorical subject. Contrastive focus intonation also allows a noun to be interpreted as a categorical subject, as in example (9) above from Hebrew, repeated here:

mi bxina evolucyonit, xatul maqdim namer from perspective evolutionary, cat precedes tiger

'From an evolutionalry perspective, the cat precedes the tiger.'

In Brazilian Portuguese, interpreting a bare subject as categorical has to be motivated by contrastivity, as shown in (47) (S\&M 2000 (12)):

a.?? Mulher esteve discutindo política

woman was discussing politics

b. Mulher esteve discutindo política, homem esteve discutindo futebol.. woman was discussing politics, man was discussing soccer...

Bare singulars, then, function as arguments of predicates by incorporation. Only in categorical subject position can they be shifted to a kind interpretation. As arguments of predicates, they have to be marked as definite in order to secure kind reference. Bare plurals and mass terms are different. Independently of the type of judgment, they can be shifted by "cap" to kinds. 
Therefore they do not have to be marked as definite, or to be categorical subjects, in order to be interpreted as kinds. Rather they are freely nominalized, as predicted by Chierchia. Indeed, examples (48)-(53), though containing predicates that can apply to ordinary objects, can all be interpreted with kind readings irrespective of the definite marker, even in the episodic examples:

(ha-)dinoza'urim kvar nikxedu lifney milyon šana (the-)dinosaurs already became-extinct before million year 'Dinosaurs were extinct a million years ago already.'

(49) (ha-)xuldot higi'u le-ostralya be 1770 (the)rats reached to-Australia in 1770 'Rats reached Australia in 1770.'

elohim bara (et ha-) taninim b a-yom ha-xamiši god created (ACC the-)crocodiles on the-day the-fifth 'God created crocodiles on the fifth day.'

profesor li xoker (et ha-) nemerim professor Li investigates (ACC the-)tigers 'Professor Li investigates tigers.'

elohim bara (et ha-) esev b a-yom ha-šliši god created (ACC the-)grass on the-day the-third 'God created grass on the third day.'

profesor li xoker (et ha-) bronza professor Li investigates (ACC the-)bronze 'Professor Li investigates bronze.'

In Russian as well, the same contrast between singular and plural is found:

a. Krysa poyavilas' v Avstralii v 1770 rat arrived in Australia in 1770

'A rat reached Australia in 1770.' $\sqrt{ }$ obj. / * kind

b. Krysy poyavilis' v Avstralii v 1770 rats arrived in Australia in 1770 'Rats reached Australia in 1770.' $\sqrt{ }$ obj. $/ \sqrt{ }$ kind

(55) a. Profesor Li izučayet tigra Professor $\mathrm{Li}$ investigates tiger 'Professor Li investigates a/the tiger.' $\sqrt{ }$ obj. / * kind

b. Profesor Li izučayet tigrov Professor $\mathrm{Li}$ investigates tigers 
'Professor Li investigates (the) tigers.' $\sqrt{ }$ obj. $/ \sqrt{ }$ kind (Olga Kagan, p.c.)
a. * Dinosavr vymer
dinosaur died-out
b. Dinosavry vymerly
dinosaurs died-out
'Dinosaurs are extinct.' (Chierchia 1998 (27e))

As in Hebrew and Brazilian Portuguese, in Russian too a bare singular in categorical subject position can refer to a kind:

$$
\begin{aligned}
& \text { Greki sčitali, što sobaku vykoval Vulkan } \\
& \text { Greeks considered that dog-SG-ACC forged Vulkan } \\
& \text { 'The Greeks thought that the dog was forged by Vulka.' } \\
& \text { (attested example, Olga Kagan p.c.) }
\end{aligned}
$$

I assume that in Hindi as well, it is the categorical subject position which is responsible for the definite interpretation of bare singulars noted by Dayal in (21), repeated below as (58):

$$
\begin{aligned}
& \text { kutta bhaunk rahaa hai } \\
& \text { dog bark-PROG-PRES }
\end{aligned}
$$

'The dog/*a dog is barking.'

In contrast, subjects which are not categorical can actually be indefinite:

$$
\begin{aligned}
& \text { aNgaN me kutta bhaunk rahaa hai } \\
& \text { yard in dog bark-PROG-PRES } \\
& \text { 'The dog/a dog is barking in the yard.' (Aditi Lahiri p.c.) }
\end{aligned}
$$

\section{Conclusion}

This paper has shown that the bareness of indefinite nouns is not a sufficient condition for kind reference. Rather, kind reference depends on the bare noun either being plural, or being the subject of a categorical judgment. This means that first, Chierchia's nominalization type-shift from properties to kinds indeed freely applies to plural properties only (despite of the Hebrew and Brazilian Portuguese examples). Second, subjects of categorical judgments are interpreted as definite. In English, Italian, Hungarian and Arabic, this requires a marking of morphological definiteness. In Hebrew and Brazilian Portuguese, it does not (and neither of course does it in Hindi and Russian, which do not mark definiteness morphologically at all). Irrespective of definiteness marking, the subject of the 
Hebrew sentence (1a), repeated here as (60), is interpreted as a kind because it is a categorical subject:

$$
\begin{aligned}
& \text { namer hu min be sakanat hakxada } \\
& \text { tiger he kind in danger (of) extinction } \\
& \text { 'The tiger is a kind in danger of being extinct.' }
\end{aligned}
$$

In addition, what characterizes languages which allow bare singular nouns in the first place (Hebrew, Arabic, Hungarian, Brazilian Portuguese, but not Italian or English) is the availabily of incorporation as the means of existential interpretation of bare nouns. The table in (61) summarizes these observations.

+ Mark Categorical

$$
\begin{array}{ccc}
\text { + Incorporating } & \text { - Incorporating } \\
+ \text { number-neutral } & - \text { number-neutral } & \text { Arabic }
\end{array}
$$

Subj. as Definite

- Mark Categorical

Subj. as Definite

$\begin{array}{ll}\text { Br. Portuguese } & \text { Hebrew } \\ \text { Hindi } & \text { Russian }\end{array}$

English

\section{Acknowledgments}

This work originates in the Logic and Language Workshop at the Hebrew University of Jerusalem. I am grateful to the participants of the workshop, to the participants of the June 2002 Linguistics International Colloquium at the University of Konstanz and of the April 2003 meeting of the Israel Semantics Circle, and to the audiences of SALT 13 and IATL 19.

\section{References}

Carlson, G. 1977. Reference to Kinds in English UMass Ph.D. diss. Published 1980, New York: Garland Press.

Carlson, G. and J. Pelletier (eds.) 1995. The Generic Book. Chicago: The University of Chicago Press.

Cheng, L. and R. Sybesma 1999. "Bare and Not-so-bare Nouns and the Structure of NP” Linguistic Inquiry 30, 509-542.

Chierchia, G. 1998. "Reference to Kinds Across Languages" Natural Language Semantics 6, 339-405.

Danon, G. 2002. "Caseless Indefinites in Hebrew", talk given at the Hebrew University of Jerusalem.

Dayal, V. 1992. "The Singular-Plural Distinction in Hindi Generics" SALT II

Dayal, V. 1999. "Bare NPs, Reference to Kinds, and Incorporation" SALT IX 
Doron, E. and C. Heycock 1999. "Filling and Licensing Multiple Specifiers" in D. Adger, S. Pintzuk, B. Plunkett and G. Tsoulas (eds.) Specifiers: Minimalist Approaches. Oxford: OUP, 69-89.

Farkas, D. and H. de Swart 2003. The Semantics of Incorporation. Stanford: CSLI Publications.

Gerstner, C. and M. Krifka 1993. "Genericity" in J. Jacobs, A. von Stechow, W. Sternefeld and T. Vennemann (eds.) Handbuch der Syntax. Berlin: de Gruyter, 966-978.

Heycock, C. and E. Doron 2003. "Categorical Subjects” Gengo Kenkyu 123, 95135.

Krifka, M. 1995. "Common Nouns: a Contrastive Analysis of Chinese and English" in G. Carlson and J. Pelletier (eds.) 1995.

Krifka, M. J. Pelletier, G. Carlson, A. ter Meulen, G. Chierchia and G. Link 1995. "Genericity: an Introduction" in G. Carlson and J. Pelletier (eds.) 1995.

Kuroda, S.-Y. 1972. "The Categorical and the Thetic Judgment" Foundations of Language 9, 153-185.

Ladusaw, W. 1994. "Thetic and Categorical, Stage and Individual, Weak and Strong" SALT IV, 220-229.

Link, G. 1983. "The Logical Analysis of Plurals and Mass Terms: a Latticetheoretical Approach" in R. Bauerle, C. Schwarze and A. von Stechow (eds.) Meaning, Use and Interpretation of Language. Berlin: de Gruyter.

Longobardi, G. 2001. "How Comparative is Semantics? A Unified Parametric Theory of Bare Nouns and Proper Names" Natural Language Semantics 9, 335-369.

Müller, A. 2001. "Genericity and the Denotation of Common Nouns in Brazilian Portuguese" in UMOP 25: Proceedings of SULA (Semantics of UnderRepresented Languages in the Americas). UMass: GLSA, 72-80.

Schmitt, C. and A. Munn. 1999. "Against the Nominal Mapping Parameter: Bare Nouns in Brazilian Portuguese" NELS 29.

Schmitt, C. and A. Munn. 2000. "Bare Nominals, Morphosyntax and the Nominal Mapping Parameter" ms. Michigan State U.

Van Geenhoven, V. 1998. Semantic Incorporation and Indefinite Descriptions. Stanford: CSLI Publications. 